\title{
Phloroglucinol pathway in the strictly anaerobic Pelobacter acidigallici: fermentation of trihydroxybenzenes to acetate via triacetic acid
}

\author{
Andreas Brune* and Bernhard Schink ** \\ Lehrstuhl Mikrobiologie I, Universität Tübingen, Auf der Morgenstelle 28, W-7400 Tübingen, Federal Republic of Germany
}

Received September 19, 1991/Accepted January 3, 1992

\begin{abstract}
The strictly anaerobic, fermenting bacterium Pelobacter acidigallici degrades several trihydroxybenzene derivatives to stoichiometric amounts of acetate. We now report on the enzymatic activities in cell extracts which are responsible for the fermentative degradation of these aromatic compounds, and postulate a novel phloroglucinol pathway involving triacetic acid as an unusual metabolic intermediate. Gallate is decarboxylated to pyrogallol by a specific, $\mathrm{Mg}^{2+}$-dependent, soluble enzyme activity, followed by conversion of pyrogallol to phloroglucinol, involving an unusual intermolecular transhydroxylation described previously. Phloroglucinol is then reduced to dihydrophloroglucinol (5-hydroxy1,3-cyclohexanedione) by an NADPH-dependent phloroglucinol reductase. Dihydrophloroglucinol is cleaved hydrolytically to 3-hydroxy-5-oxohexanoic acid, which is then oxidized to triacetic acid (3,5-dioxohexanoic acid) by a unique, $\mathrm{NADP}^{+}$-dependent dehyơrogenase. Triacetic acid is activated by $\mathrm{CoA}$ transfer from acetyl-CoA, and then converted to 3 acetyl-CoA by two subsequent $\beta$-ketothiolase reactions. ATP is generated via phosphotransacetylase and acetate kinase.
\end{abstract}

Key words: Trihydroxybenzenes - Anaerobic degradation - Aromatic compounds - Phloroglucinol pathway - Ring cleavage - 3-Hydroxy-5-oxohexanoic acid Beta-oxidation - Triacetic acid (3,5-dioxohexanoic acid) - Pelobacter acidigallici

\footnotetext{
* Present address: Department of Microbiology and Public Health, Michigan State Unıversity, East Lansing, MI 48824-1101, USA

** Present address and address for correspondence: B. Schink, Fakultät Cür Biologie, Postfach 5560 , W-7750 Konstanz, Federal Republic of Germany
}

Abbreviations: CoA, coenzyme A; CTAB, cetyltrimcthylammonium bromide; DTT, 1,4-dithiothreitol; HOHA, 3-hydroxy-5-oxohexanoic acid; IIPLC, high performance liquid chromatography; TAA, triacetic acid (3,5-dioxohexanoic acid); Tris, tris-(hydrocymethyl)aminomethane
Pelobacter acidigallici degrades the trihydroxybenzenes pyrogallol (1,2,3-trihydroxybenzene) and phloroglucinol (1,3,5-trihydroxybenzene), and their carboxylated derivatives to stoichiometric amounts of acetate (Schink and Pfennig 1982). Pyrogallol is converted to phloroglucinol by a novel transhydroxylase reaction involving $1,2,3,5$ tetrahydroxybenzene as cosubstrate (Brune and Schink $1990 \mathrm{a})$. The third trihydroxybenzene isomer, hydroxyhydroquinone $(1,2,4$-trihydroxybenzene), is not utilized by $P$. acidigallici, but is degraded by $P$. massiliensis, a species fermenting all 3 trihydroxybenzene isomers to acetate (Schnell et al. 1991). Again, phloroglucinol is the key intermediate formed in a sequence of several transhydroxylation reactions (Brune et al. 1991).

Little is known about the other reactions involved in trihydroxybenzene degradation by $P$. acidigallici. An accumulation of pyrogallol or phloroglucinol by dense cell suspensions grown on the respective carboxylated substrates has been reported for $P$. acidigallici strain AG2 (Samain et al. 1986). Phloroglucinol is reduced by an NADPH-dependent oxidoreductase (Schink and Pfennig 1982; Samain ct al. 1986). The further reactions of the pathway are to date unknown.

The pathway of anaerobic degradation of trihydroxybenzenes has been studied only with one other bacterium. Eubacterium oxidoreducens uses essentially the same initial reactions as $P$. acidigallici, but differs strongly with respect to its obligate dependency on external electron donors, formate or hydrogen, and the formation of reduced fermentation products in addition to acetate (Krumbolz et al. 1987). Again, phloroglucinol is the key metabolic intermediate; the NADPH-dependent phloroglucinol reductase has been purified (Haddock and Ferry 1989). With E. oxidoreducens, 3-hydroxy-5-oxo-hexanoate (HOHA) was identified as product formed from dihydrophloroglucinol upon incubation with cell extracts, probably by hydrolytic cleavage (Krumholz et al. 1987). Enzymes involved in butyrate and acetate formation from 3-hydroxybutyrate were demonstrated, however, activation of HOHA and its cleavage to a. $\mathrm{C}_{4}$-acid could not be completely clarified ( $\mathrm{K}$ rumholz et al. 1987).

In this paper we demonstrate all enzymes involved in 
a novel pathway for conversion of trihydroxybenzenes to 3 acetate in $P$. acidigallici.

\section{Materials and Methods}

\section{Chemicals}

XAD-2 was purchased from Serva (Heidelberg, FRG); all other commercial sources were as previously published (Brune and Schink 1990b).

Dihydrophlorogiucinol was prepared by chemical reduction of phloroglucinol with sodium borohydride according to Patel et al. (1981), lyophilized, and separated from residual borate and phloroglucinol by column chromatography on $\mathrm{XAD}-2$ $(0.05-0.1 \mathrm{~mm}$; column $500 \times 10 \mathrm{~mm})$ in water. Contrary to the report of Fray (1958), no resorcinol was formed under these conditions. Identity and purity were confirmed by UV spectroseopy $\left(\lambda_{\max }=278 \mathrm{~nm}\right)$ and HPLC (see below).

Triacetic acid (3,5-dioxohexanoic acid, TAA) was synthesized as follows: TAA methyl ester was prepared from dehydroacetic acid (3-acetyl-4-hydroxy-6-methyl-2-pyrone) by boiling in methanol/magnesium methoxide (Batelaan 1976), and was positively identified by H-NMR and mass spectroscopy. The product contained triacetic acid lactone (6-methyl pyranone), the themal decomposition product of TAA methyl ester (Batelaan 1976), as a major impurity, but was used without further purification. Saponification of the methyl ester was performed at mildly alkaline conditions in dilute aqueous solution in the cold (which left the diketone structure unaffected); a method thoroughly studied by Witter and Stotz (1948a) with the ethyl ester. Acidification to $\mathrm{pH} 2.5$ precipitated most impurities stemming fiom the crude methy] cster preparation. After centrifugation, the supernatant was lyophilized; the resulting TAA preparation was about $65 \%$ pure, as calculated from the UV absorbance of the preparation $\left(\varepsilon_{275}=3.01 \mathrm{mM}^{-1} \mathrm{~cm}^{-1}\right.$; Meister 1949) and its HPLC chromatogram at $275 \mathrm{~nm}$. Attempts to further purify TAA failed duc to its extreme instability in organic solvents and in aqueous solution, and its rapid spontaneous decarboxylation. as already observed by Witter and Stolz (1948a). However, all impurity peaks in the HPLC chromatogram remained unchanged under the experimental conditions employed.

\section{Preparation of cell suspensions and cell extracts}

Pelobacter acidigallici strain MaGal2 (DSM 2377) was grown in a bicarbonate-buffered, sulfide-reduced mineral medium under a $\mathrm{N}_{2} \mathrm{CO}_{2}$ atmosphere (Brune and Schink 1990a). Sodium gallate or other aromatic substrates $(7.5 \mathrm{mM})$ were added from filtersterilized. anoxic stock solutions. Cell suspensions and cell extracts were prepared as described (Brune and Schink 1990a). When indicated, cell extracts were dialyzed directly after preparation for $8 \mathrm{~h}$ in K-phosphate buffer (100 $\mathrm{mM}$, pH 7.0), containing DTT $(2.5 \mathrm{mM})$ and $\mathrm{MgCl}_{2}(10 \mathrm{mM})$. All steps were performed under strict exclusion of air at $0-4^{\circ} \mathrm{C}$. Cell suspensions were permeabilized by addition of CTAB to a final concentration of $0.1 \mathrm{~g} / 1$ which was sufficient for complete permeabilization to pyridine nucleotides in the phloroglucinol reductase assay. Since permeabilization was insufficient to allow free entry of $\mathrm{COA}$ and its thiocsters into the cells, the respective assays were always performed with cell extracts.

\section{Determination of enzyme activities}

Enzyme activities were determined at $25^{\circ} \mathrm{C}$ under strict exclusion of oxygen, either in spectrophotometrical assays (Brunc and Schink $1990 \mathrm{~b}$ ), or in assays discontinuousty analyzed by HPLC (Brune and Schink 1990a). Samples were kept at $0^{\circ} \mathrm{C}$ until analyzed, or were frozen at $-20^{\circ} \mathrm{C}$. All values are means of at least two independent assays of less than $10 \%$ variation performed with different cell extracts. Spectrophotometrical assays usually containef 5-50, discontinuous assays $50-150 \mu \mathrm{m}$ protein $\mathrm{ml}^{-1}$. A linear relationship between observed activity and protein concentration was granted in all cases. Protein was quantilated by the micro-pratein assay described by Bradford (1976), with bovine serum albumin as a standard.

Gallate decarboxylase (EC 4.1.1.59) and decarboxylation of 2,3,4- and 2,4,6-trihydroxybenzoate was routinely assayed spectrophotometrically following substrate disappearance upon addition of cell extract. The extinction coefficients at the respective absorbance maxima were approximately $8.3(259 \mathrm{~nm}), 9.6$ (255 $\mathrm{nm})$, and $7.7 \mathrm{mM}^{-1} \mathrm{~cm}^{-1}(255 \mathrm{~nm})$. The assay mixture contained K-phosphate buffer (pH 7.0), $100 \mathrm{mM} ; \mathrm{MgCl}_{2}, 10 \mathrm{mM}$; DTT, $2.5 \mathrm{mM}$; and the respective Na-trihydroxybenzoate, $0.1 \mathrm{mM}$. If analyzed by HPLC, trihydroxybenzaate concentrations were increased to $0.65 \mathrm{mM}$.

Tetrahydroxybenzene: pyrogallol hydroxyltransferase (EC 2.-.-..-) was assayed by discontinuous HPLC analysis (Brune and Schink 1990a), 1,2,3,5-tetrahydroxybenzene and pyrogallol were each $1 \mathrm{mM}$.

Phlorogiucinol reductase (EC 1.1.1...) was measured spectrophotometrically after Whittle et al. (1976), or by discontinuous HPLC analysis of phloroglucinol and dihydrophloroglucinol. The spectrophotometrical assay contained K-phosphate buffer $(\mathrm{pH} 7.0)$, $100 \mathrm{mM}$; phloraglucinol, $5 \mathrm{mM}$; and NADPH or NADH, $0.25 \mathrm{mM}$. For discontinuous assays, phloroglucinol and pyridine nucleotides concentrations were increased to $1 \mathrm{mM}$

Dihydrophlorogiucinol hydrolase (EC 3.7.1.-) was assayed by discontinuous HPLC analysis of dibydrophloroglucinol decrease upon addition of cell extract. The assay mixture contained K-phosphate buffer (pH 7.0), $100 \mathrm{mM} ; \mathrm{MgCl}_{2}, 10 \mathrm{mM}$; DTT, $2.5 \mathrm{mM}$; and dihylrophloroglucinol, $0.25-100 \mathrm{mM}$. Spectrophotometric measurement at $278 \mathrm{~nm}$, as reported by Krumholz et al. (1987), was not possible since the permissive dihydrophloroglucinol concentrations in the assay mixture were rather low $\left(\varepsilon_{278}\right.$ $=25 \mathrm{~nm}^{-1} \mathrm{~cm}^{-1}$ ), and limited the reaction tates considerably.

3-Hydroxy-5-axohexanoate (HOHA) dehydrogenase

(EC 1.1.1.-) was measured following NAD(P)H oxidation with TAA spectrophotometrically at $365 \mathrm{~nm}$. The standard assay mixture contained K-phosphate buffer $(\mathrm{pH} 7.0), 100 \mathrm{mM}$; NADH or NADPH, $0.25 \mathrm{mM}$; and TAA, $1 \mathrm{mM}$.

3-Fydroxyacyl-CoA dehydrogenase (EC 1.1.1.35-36), and 3hydroxybutyrate dehydrogencse (EC 1.1.1.30) assays were basically identical to the HOHA dehydrogenase assay, except that $\mathrm{Li}$ acetoacetate, $10 \mathrm{mM}$, or $\mathrm{Na}_{3}$-acetoacetyl-CoA, $0.3 \mathrm{mM}$, were substituted for TAA. The reverse reactions were tested with $\mathrm{NAD}^{+}$ or $\mathrm{NADP}^{+}, 5 \mathrm{mMM}$; and $\mathrm{Li}_{3}-\mathrm{DL}-\beta$-hydroxybutyryl-CoA, $1 \mathrm{mM}$, or Na-DL-3-hydroxybutyrate, $10 \mathrm{mM}$.

Acetyl-CaA:iriccetate CoA transferase (EC 2.8.3.-) was measured by discontinuous HPLC analysis of TAA decrease upon addition of acetyl-CoA. The assay mixture contained $\mathbf{K}$-phosphate buffer ( $\mathrm{pH}$ 7.0), $100 \mathrm{mM}$; TAA, $3 \mathrm{mM}$; acetyl-CoA, $0.5 \mathrm{mM}$; and CoA, $0.5 \mathrm{mM}$

Acetyl-CoA acetoacetate CoA transfercase (EC 2.8.3.-) and succinyl.CoA:acetoacetate CoA transferase (EC 2.8.3.5) were measured in the spectrophotometrical assay used for $\beta$-keto thiolase determination (see below), except that Na-acetate or Na-succinate, both $10 \mathrm{mM}$, replaced CoA. The reverse reactions were andlyzed analogously to the acetyl-CoA:TAA CoA transferase assay by discontinuous HPLC analysis.

Acetoacetyl-CoA thiolase (LC 2.3.1.9) was measured spectrophotometrically at $303 \mathrm{~mm}$ by recording the disappearance of acctoacetyl-CoA upon addition of CoA (Lynen and Ochoa 1953) using $\varepsilon_{3 a_{3}}=14.0 \mathrm{mM}^{-1} \mathrm{~cm}^{-1}$ determined for the acetoacelyl$\mathrm{CoA} / \mathrm{Mg}^{2+}$ complex (Stern 1956). The assay contained Tris-HCl buffeт ( $\mathrm{pH} 8.3$ ), $100 \mathrm{mM} ; \mathrm{MgCl}_{2}, 10 \mathrm{mM}$; $\mathrm{Na}_{3}$-acetoacelyl-CoA, $0.1 \mathrm{mM}$; and $\mathrm{Li}_{3}-\mathrm{CoA}, 0.1 \mathrm{mM}$. Enzyme activity was corrected for instability of acetoacetyl-CoA with dialyzed cell extract prior to addition of $\mathrm{COA}$.

Triacety-COA thiolase (EC 2.3.1.-) and acetoacety-COA thiolase were measured following acetyl-CoA formation and $\mathrm{CoA}$ 
decrease in a coupled assay in which the 3-oxnacyl-CoA esters were produced by the respective CoA transferase reactions with acetyl-CoA. The assay mixture was identical to that already described for acetyl-CoA triacetate $\mathrm{CoA}$ transferase except that Tris-HCl buffer (pH 7.3) was used. For calculation of specific activities in the assays with TAA, the rate of acetyl-CoA formation was equally attributed to the thiolytic cleavage of TAA-CoA and aceloacely $\mathrm{l}-\mathrm{CoA}$.

Phosphotransacetylase (EC 2.3.1.8) was assayed spectrophotometrically (modified after Michal and Bergmeyer 1974). The assay mixture contained Tris-IICl (pII 7.3), $100 \mathrm{mM}$ : Li-K-acetyl phosphate, $3 \mathrm{mM}$; and $\mathrm{Li}_{3}-\mathrm{CoA}, 0.25 \mathrm{mM}$.

Acetate kinase (EC 2.7.2.1) was measured after Bergmeyer et al. (1974). Dialyzed cell extracts had to be used due to the high background reaction, which was further reduced by incubating the assay mixture with $5 \mu \mathrm{m} N, N^{\prime}$-dicyclohexylearbodimide (DCCD $0.1 \mu$ mol mg protein ${ }^{-1}, 1 \mathrm{mM}$ ethanolic stock solution), for $10 \mathrm{mits}$ before starting the reaction.

\section{Analytical methods}

Aromatic compounds, dihydrophloroglucinol, $\mathrm{TA}, \mathrm{Co} A$ and $\mathrm{CO} A$ esters were analyzed by HPLC (Brune and Schink 1990a). Aromatic compounds and dihydrophloroglucinol were separated on an Ultrasphere-ODS column $(4.6 \times 150 \mathrm{~mm}$, Beckman Instruments, München, FRG), using a $100 \mathrm{mM}$ ammonium phosphate-bu(fer mcthanol solvent system ( $\mathrm{pH} 2.6)$, of varying composition. For CaA esters and TAA, a column $(250 \times 4 \mathrm{~mm})$ filled with LlChrospher $100 \mathrm{RP}-18$ endcapped $(5 \mu \mathrm{m})$ stationary (Merck, Darmstadt, FRG) was used. The mobile phase consisted of (A) 50 mM K-phosphate buffer (pII 6.4), and (B) methanol Composition changed according to the following routine: injection, $16 \% \mathrm{~B}$; $2.5 \mathrm{~min}$, linear gradient to $25 \% \mathrm{~B}$ in $2 \mathrm{~min} ; 5 \mathrm{~min}, 16 \% \mathrm{~B} ; 10 \mathrm{~min}$, next injection.

Data were computer-analyzed and quantitated by comparing peak areas with external and internal standards of known composition. Peaks were routinely idcntificd by on-line spectral scans and comparison with reference compounds via retention times and UV spectra.

Volatile fatty acids were analyzed by gas chromatography (Platen and Schink 1987).

\section{Results}

\section{Reactions preparing aromatic substrates for ring cleavage}

Gallate-grown cell suspensions of Pelobacter acidigallici converted gallate to acetate at in vivo rates without significant accumulation of aromatic intermediates. Higher concentrations of pyrogallol or phloroglucinol in the supernatant, as reported by Samain et al. (1986), occurred only if the suspensions were insufficiently buffered. However, when cells werc permeabilized with CTAB or disrupted by French Press treatment, pyrogallo] accumulated stoichiometrically with gallate consumption (Fig. 1).

The specific activity (Table 1) and stability of gallate dccarboxylase in cell extracts depended strongly on the presence of $\mathrm{Mg}^{2+}$. Maximum activity was reached with $15 \mathrm{mM} \mathrm{MgCl}_{2}$ in the reaction mixture; the apparent $K_{\mathrm{m}}$ for $\mathrm{Mg}^{2+}$ was $5 \mathrm{mM}$ (not shown). After ultracentrifugation of cell extracts at $200000 \times \mathrm{g}$ for $60 \mathrm{~min}$, the activity was completely recovered in the supernatant. 2,3,4- and 2,4,6-trihydroxybenzoate were not decarboxylated by extracts of gallate-grown cells, nor did $P$. acidigallici grow with 2,3,4-trihydroxybenzoate. Growth with 2,4,6-trihy-

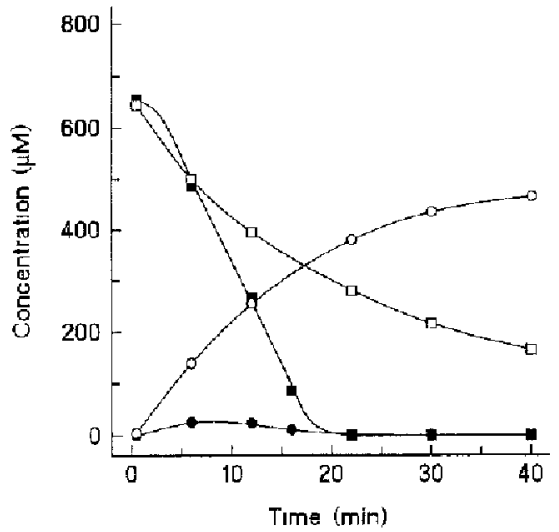

Fig. 1. Metabolism of gallate by intact (ם) or CTAB-permeabilized ( $\square$ ) cell suspension of Pelobacter acidigallici ( $80 \mu \mathrm{g}$ protein $\mathrm{ml}^{-1}$ ), and the corresponding pyrogallol concentrations $(\bullet, 0)$

Table 1. Enzymes involved in modification of aromatic substrates and in ring cleavage by Pelobacter acidigallici

\begin{tabular}{|c|c|c|}
\hline \multicolumn{2}{|c|}{ Enzyme $^{a}$} & \multirow{2}{*}{$\begin{array}{l}\begin{array}{l}\text { Spccific activity } \\
\text { [nmol }\end{array} \\
\frac{570^{\mathrm{c}}}{\text { (min } \cdot \text { mg protein })^{-1}}\end{array}$} \\
\hline 1 & Gallate decarboxylase & \\
\hline 2 & $\begin{array}{l}\text { 1,2,3,5-Tetrahydroxy } \\
\text { benzene : pyrogallol } \\
\text { transhydroxylase }\end{array}$ & 890 \\
\hline 3 & $\begin{array}{l}\text { Phloroglucinol reductase } \\
\text { (NADPH-dependent) }\end{array}$ & $4980^{\mathrm{c}}$ \\
\hline 4 & $\begin{array}{l}\text { Dihydrophloroglucinol } \\
\text { hydrolase }\end{array}$ & 3140 \\
\hline
\end{tabular}

droxybenzoate was slower as compared to growth with gallate; spontancous decarboxylation of this compound to phloroglucinol could not be ruled out.

Pyrogallol was converted to acetate by cell suspensions without significant lag phase only if the cells were grown with pyrogallol. With intact cells, no aromatic intermediates accumulated. If suspensions were permcabilized with CTAB or if cells were disrupted by French Press treatment, the pyrogallol concentration did not change. Upon addition of the cosubstrate 1,2,3,5-tetrahydroxybenzene, pyrogallol was instantaneously and completely converted to phloroglucinol (Table 1).

Phloroglucinol, which is also metabolized only by intact cells, is reduced to dihydrophloroglucinol by cell extracts or permeabilized cells if NADPH is added as cosubstrate (Table 1). With NADH, the activity was $<3 \%$ as compared to NADPH. In the reverse direction, an $\mathrm{NADP}^{+}$-dependent reoxidation of chemically synthesized dihydrophloroglucinol to phloroglucinol was confirmed (data not shown).

\section{Cleavage of dihydrophloroglucinol}

Dihydrophloroglucinol was stable in control experiments with boiled cell extracts, but was completely metabolized 


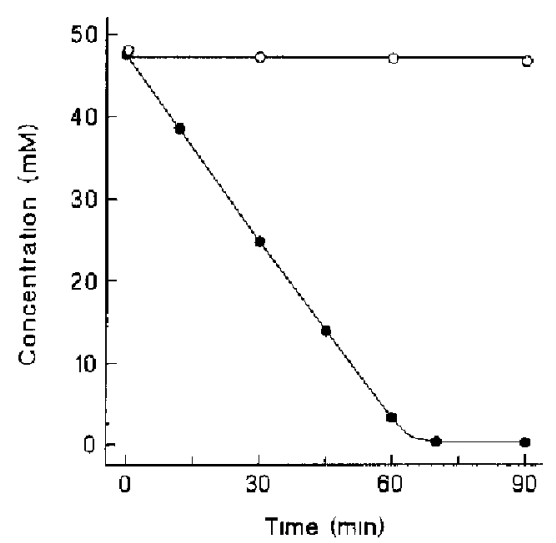

Fig. 2. Stability of dihydrophloroglucinol in the presence of fresh (-) and boiled (O) P. acidigallicicell extract ( $240 \mu \mathrm{g}$ protein $\mathrm{ml}^{-1}$ )

to an unknown product by both permeabilized cells and cell extracts (Fig. 2; Table 1). From experiments with various dihydrophloroglucinol concentrations, an apparent $K_{\mathrm{m}}$ of approximately $1 \mathrm{mM}$ was estimated. The reaction is presumably hydrolytic since it was not influenced by the presence of $\mathrm{Co} \Lambda$ or phosphate in the assay mixture. The reaction was not stimulated by the addition of $0.25 \mathrm{mM} \mathrm{CoA}$, nor was it impeded if the phosphate buffer was replaced by Tris, neither with freshly prepared nor with dialyzed cell extracts. There was also no indication of $\mathrm{CoA}$ ester formation in the HPLC chromatogram if $0.25 \mathrm{mM}$ acetyl-CoA or $0.25 \mathrm{mM}$ CoA plus $2.5 \mathrm{mM}$ ATP was included in the assay.

\section{Enzymes of $\beta$-oxidation and formation of $A T P$}

Cell extracts did not contain 3-hydroxybutyrate dehydrogenase or 3-hydroxyacyl-CoA dehydrogenase, i.e. they did not reduce acetoacetate or its CoA-ester, neither with NADH nor with NADPH. However, if in the sume assay acetoacetate was replaced by chemically synthesized triacetic acid (TAA, 3,5-dioxohexanoic acid), NADPH was rapidly oxidized. Specific activity of this enzyme, referred to as 5-oxo-3-hydroxyhexanoate (HOHA) dchydrogenase, was the highest of all enzymatic activities observed with this organism (Table 2). The activity was stable under both anaerobic and aerobic assay conditions, and remained unchanged after freezing $\left(-20^{\circ} \mathrm{C}\right)$ or storage of cell extracts on ice for $24 \mathrm{~h}$. Kinetic characterization showed a pronounced specificity for TAA $\left[K_{\mathrm{m}}=0.36 \mathrm{mM}, V_{\max }=34.4 \mu \mathrm{mol} \cdot(\mathrm{min} \cdot \mathrm{mg}\right.$ protein $)^{-1}$; see Fig. 3] and NADPH $\left[K_{\mathrm{m}}=66 \mu \mathrm{M}\right.$, $\left.V_{\max }=31.1 \mu \mathrm{mol} \cdot\left(\min ^{-1} \cdot \mathrm{mg} \text { protein }\right)^{-1}\right]$. Acctoacetate could not replace TAA, and NADH was oxidized with only $4 \%$ of the activity observed with NADPH.

If TAA was incubated with cell extracts in the absence of NADPH, its concentration remained unchanged, as compared to controls lacking cell extract. Furthermore, acetoacetate formation from TAA could be excluded since NADH oxidation by cell extracts in the presence of TAA was not increased if commercial 3-hydroxybutyrate dehydrogenase was added. However, if acelyl-CoA was addcd, TAA was consumed, indicating the presence
Table 2. Enzymes involved in $\beta$-oxidation, formation of acetylCoA. and substrate-level phosphorylation by $P$. acidigallici

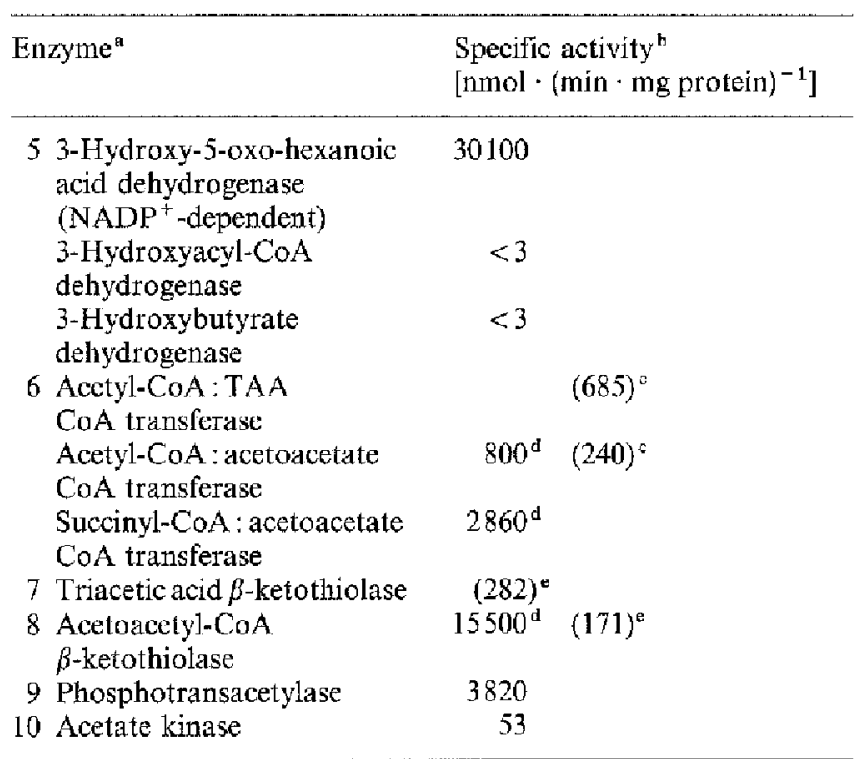

a Number designation as in Fig. 5

${ }^{h}$ Gallate-grown cells

- Decrease of free acid in HPLC assay (rate limited)

d Accloacetyl-CoA decrease in spectrophotometrical assay

- Acetyl-CoA formation in HPLC assay (rate limited)

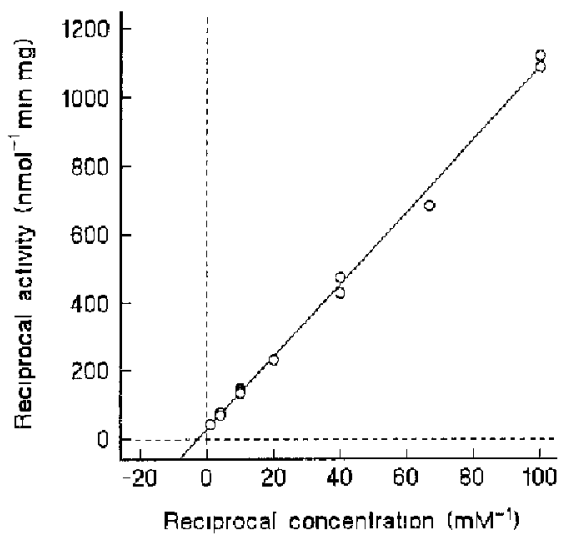

Fig. 3. Double reciprocal plot of TAA reductase act1vity versus TAA concentration. See text for apparent $K_{m}$ and $V_{\text {max }}$ values fitting the regression curve. The assay mixtures contained cell extract with $5 \mu \mathrm{g}$ proteiti $\mathrm{ml}^{-1}$

of an acetyl-CoA:TAA CoA transferase. Addition of free CoA to the rcaction mixture gave higher reaction rates (Table 2), but this was not mandatory since CoA was endogenously formed from acetyl-CoA (see below). Figure $4 \mathrm{~A}$ represents a typical time course of this reaction. Most interestingly, the initial acctyl-CoA concentration did not decrease but rather increased concomitant with TAA consumption. accompanied by a stoichiometric ( $1: 1)$ decrease of free CoA. No acetoacetyl-CoA nor any peak indicating an intermediary accumulation of TAA-CoA was observed in the HPLC chromatogram of the assay mixture. Apparently, two subsequent $\beta$-ketothiolytic activities acting on the CoA esters of TAA and acetoacetate prevent accumulation of 


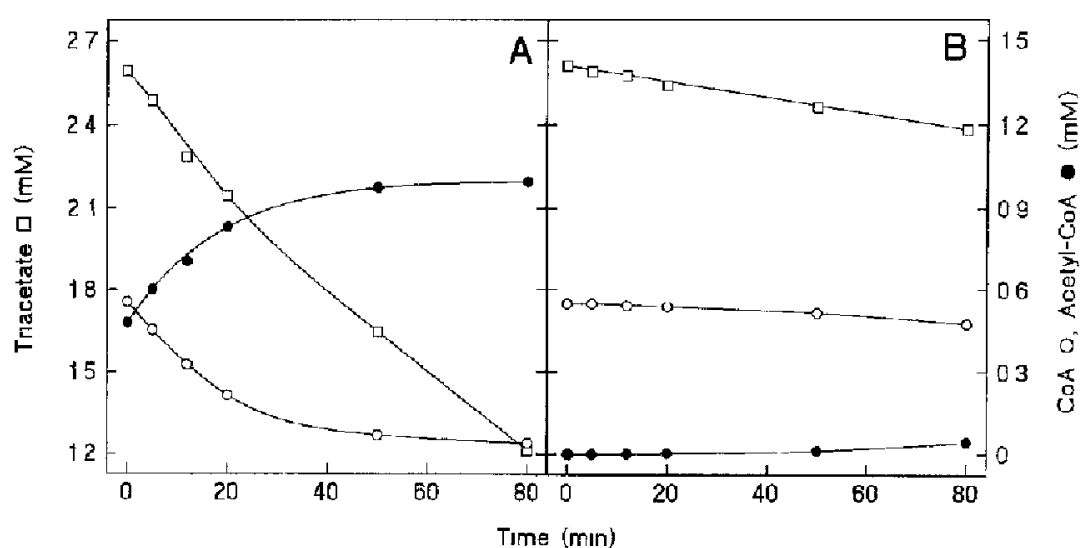

Fig. 4. Formation of acetyl-CoA (-) from TAA (D) and $C O A(O)$ in the presence $(A)$ or in the absence $(B)$ of initial acetyl-CoA $(0.5 \mathrm{mM})$. Both assays contained cell extracts with $125 \mu \mathrm{g}$ protein $\cdot \mathrm{ml}^{-1}$ these metabolites to higher concentrations. The rate of acetyl-CoA formation was always considerably lower than that of TAA consumption. This discrepancy was markedly higher in phosphate-buffered assay mixtures as compared to those with Tris buffer, reflecting the instability of acetyl-CoA in the presence of cell extracts, which was also observed in control experimente and is probably due to the regeneration of free $C O A$ from acetyl-CoA by a highly active phosphotransacetylase (Table 2). Acetate accumulated as final product.

Similar results were obtained when in analogous experiments TAA was replaced by acetoacetate, but specific activities were lower (Table 2). Higher activities of acetoacetyl-CoA : acetate CoA transferase were determined in spectrophotometric assays (Table 2) which allowed a more sensitive and direet measurement of acetoacetyl-CoA decrease. Unfortunately, direct measurement of this activity with TAA-CoA was not possible since all efforts to chemically synthesize the latter compound were unsuccessful. An acetoacetyl-CoA: succinate CoA transferase was found in a spectrophotometric assay as well (Table 2), but if succinyl-CoA was substituted for acetyl-CoA in the experiment shown in Fig. 4, acetyl-CoA formation from TAA had a significant lag phase. This implies that $\mathrm{COA}$ is not directly transferred from succinyl-CoA to TAA, but that the reaction is initiated by acetyl-CoA formation by other means. This is supported by the observation that acetylCoA formation from TAA was initiated even in the absence of acetyl-CoA, provided that CoA was present and phosphate buffer was used. This phenomenon may again be explained by the formation of catalytic amounts of acetyl-CoA by phosphotransacetylase. Use of dialyzed extracts and Tris buffer suppressed this reaction.

A highly active $\beta$-ketothiolase catalyzed the thiolytic cleavagc of acetoacetyl-CoA (Table 2). It is not possible to decide whether the same $\beta$-ketothiolase is responsible for the conversion of TAA-COA to acetoacetyl-CoA.

The acetyl-CoA finally formed by the two subsequent thiolytic cleavages was converted to acetyl-phosphate by a highly active phosphotransacetylase (Table 2). Substrate level phosphorylation via acetate kinase was detectable only at low specific activities, because the assay was severely hampered by high ATPase activity in the cell extracts. Dialysis and preincubation with DCCD reduced the background sufficiently to allow positive identification of acetate kinase activity (Table 2 ).

\section{Discussion}

The combined results of earlier investigations and of the experiments presented in this report finally allow the completion of the reaction sequence involved in trihydroxybenzene degradation in Pelobacter acidigallici (Fig. 5). This "phloroglucinol pathway" proved to be unique in the intermolecular transhydroxylation reaction converting pyrogallol to phloroglucinol, and in the occurrence of triacetic acid as an intermediate in the fermentative breakdown of the six-carbon core of the ring cleavage product to 3 acetate residues.

The results obtained in this study regarding the reactions preparing the trihydroxybenzene derivatives for ring cleavage are in general agreement with the other reports on $P$. acidigallici and other trihydroxybenzenedegrading bacteria. The presence of enzymatic activities in $P$. acidigallici decarboxylating the trihydroxybenzoates gatlate and phloroglucinol carboxylate to the respective tribydroxybenzenes had been already postulated by Schink and Pfennig (1982) on the basis of growth experiments. Later, Samain et al. (1986) observed a transient accumulation of pyrogallol or phloroglucinol in dense cell suspensions of $P$. acidigallici strain $\mathrm{AG} 2$ (DSM 3663) when incubated at high concentrations with several carboxylated derivatives. Strain MaGal2, however, did not grow on 2,3,4-trihydroxybenzoate, nor was this compound decarboxylated by extracts of gallate-grown cells. The same was true for $2,4,6-$ trihydroxybenzoate; the ability of this compound to serve as a growth substrate may be inferred by its spontaneous decarboxylation to phloroglucinol, since neutralized aqueous stock solutions were never free of phloroglucinol. In the light of these observations, the reporled NADPH-dependent reduction of 2,4,6-trihydroxybenzoate by cell extracts of strain AG2 (Samain et al. 1986) should be reconsidered. The low specilic activity of gallate decarboxylase in cell extracts of Eubacterium oxidoreducens (Krumholz et al. 1987) may be explained by the lack of $\mathrm{Mg}^{2+}$-ions in the respective assay mixture, a prerequisite for enzyme stability and activity in our experiments. 

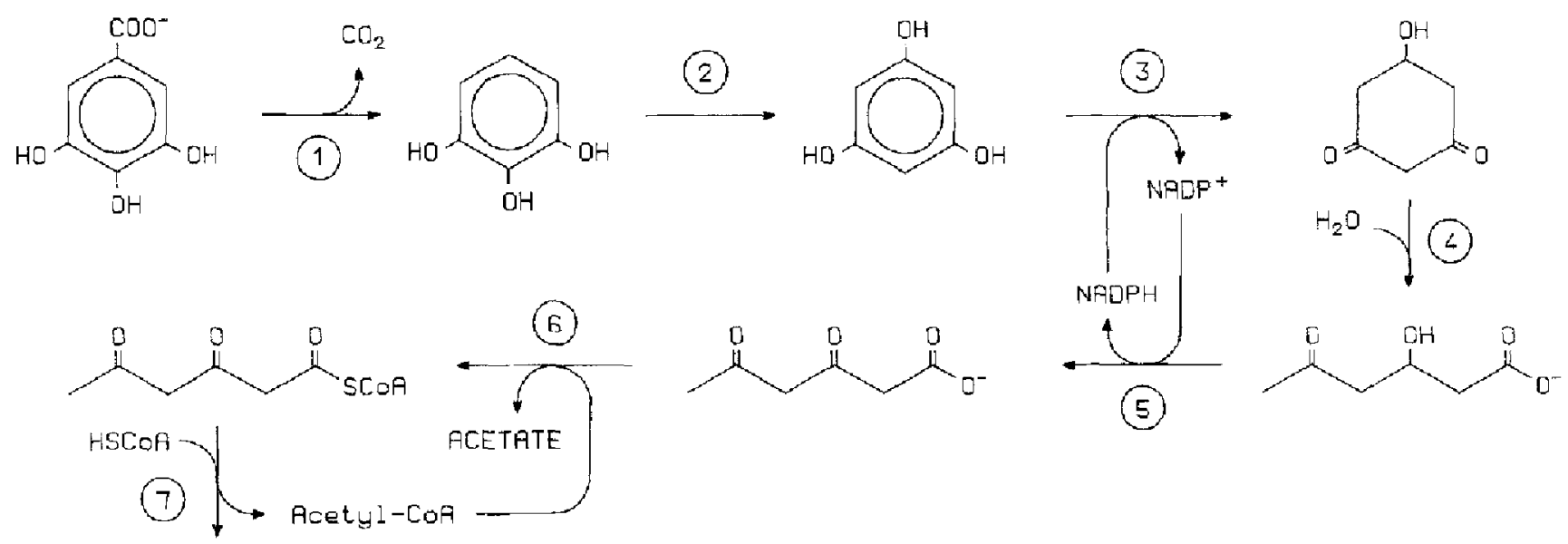<smiles>CSC(=O)CC(C)=O</smiles>

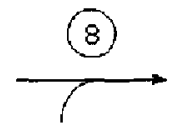

HSCoF
2 Acetyl-CoA

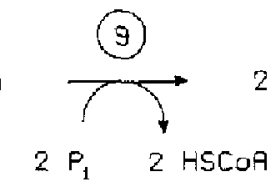

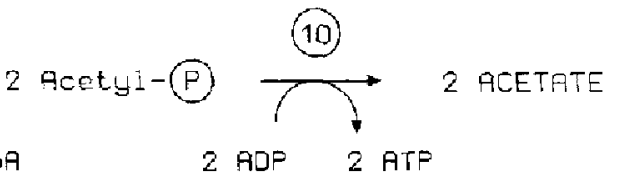

Fig. 5. Phloroglucinol pathway proposed for trihydroxybenzene degradation in $P$. acidigallici. The reaction numbers correspond to the enzyme activities given in Tabies 1 and 2

Decarboxylation of trihydroxybenzenes is not difficult to envisage. Thermal decarboxylation of gallate occurs in neutral aqueous solution upon autoclaving (Snow Boles et al. 1988), and spontaneous decarboxylation of 2,4,6-trihydroxybenzoate represented an experimental problem even at room temperature. Decarboxylation of monohydroxybenzoates to phenol involves free energy changes $\left(\Delta \mathrm{G}^{\circ}\right)$ in the range of -19 to $-21 \mathrm{~kJ} \cdot \mathrm{mol}^{-1}$ (calculated after Thauer et a1. 1977). Contrary to sodium ion-pumping decarboxylases acting on scveral aliphatic acids (Dimroth 1987), the gallate-decarboxylating activity in $P$. acidigallici was found only in the soluble fraction of French Press extracts of gallate-grown cells (data not shown). It is possible that the equilibrium of the initial reaction is responsible for creating a substrate sink in the cell in order to enable gallate uptake by facilitated diffusion, a mechanism postulated for hydroxybenzoate uptake in Rhodopseudomonas palustris (Harwood and Gibson 1986).

Conversion of pyrogallol to phloroglucinol is caused by an intermolecular transhydroxylation reaction (Brune and Schink 1990a) which proved to strictly depend on the presence of 1,2,3,5-tetrahydroxybenzene as hydroxyl donor in the assay. Hydroxyhydroquinone, the third isomer of trihydroxybenzene, is not a growth substrate for $P$. acidigallici. Our studies with $P$. massiliensis showed that hydroxyhydroquinone conversion to phloroglucinol involves a sequence of at least three individual transhydroxylation reactions, one of which is not catalyzed by P. acidigallici cell extracts (Brune et al. 1992).

$P$. acidigallici reduces phloroglucinol to dihydrophloroglucinol in a specifically NADPH-dependent reaction. This appears to be the principle in many anaerobic bacteria preparing the aromatic nucleus of phloroglucinol for ring cleavage. The reaction was observed in the photometabolism of Rhodopseudomonas growing on phloroglucinol (Whittle et al. 1976), later with a strictly anaerobic Coprococcus sp. (Patel et al. 1981) and E. axidoreducens (Krumholz et al. 1987), in which dihydrophloroglucinol was identified as the reduction product. A direct hydrogenation of pyrogallol and gallate, as postulated by Kaiser and Hanselmann (1982), was never confirmed. The phloroglucinol reductase of $E$. oxidoreducens has been purified and characterized by Haddock and Ferry (1989). The first report on a phloroglucinol reductase, however, was published by Blackwood et al. (1970) for a Pseudomonas sp. growing aerobically on phloroglucinol. The same initial reaction is also catalyzed by aerobic fungi (Patel et al. 1990), but in both cases degradation does not proceed via the phloroglucinol pathway but involves oxygenase reactions.

Dihydrophloroglucinol is not stable in the presence of $P$. acidigallici cell cxtracts. Hydrolytic cleavage is most probable, considering that the $\beta$-oxidative step to TAA occurs at the free acid level. Morcover, no stimulating effect of $\mathrm{COA}$ or acetyl-COA on the reaction could be demonstrated, and no CoA esters other than those added were detected by HPLC. 2-Oxo-4-hydroxyadipate was postulated as the hydrolysis product for Rhodopseudomonas gelatinosa (Evans 1977; Evans and Fuchs 1988), but Krumholz et al. (1987) isolated and identified 3-hydroxy5-oxo-hexanoate ( $\mathrm{HOHA})$ as the product of dihydrophloroglucinol hydrolysis in E. oxidoreducens. This and the presence of TAA reductase in $P$. acidigallici strongly indicate that the ring fission reaction occurs at the $\beta$-diketo function formed by the enol-ketone tautomerism of dihydrophloroglucinol.

No 3-hydroxyacyl-CoA debydrogenase or 3-hydroxybutyrate dehydrogenase activity was present in $P$. acidigallici, however, NADPH was rapidly oxidized by TAA. This acitivity is most probably the reverse reaction of a HOHA dehydrogenase which $\beta$-oxidizes HOHA to TAA at the free acid level. Apparently, the enzyme does not 
react with 3-hydroxybutyrate or acetoacetate, since we did not find 3-hydroxybutyrate dehydrogenase activity in cell cxtracts. Vice versa, commercial Rhodopseudomonas spheroides 3-hydroxy-butyrate dehydrogenase reacted only very slowly with TAA (specific activity less than $3 \%$ of that with acetoacetate), an observation already reported by Brock and Williamson (1985) for a similar enzyme of non-specified origin. Apparently, the low specificity for 3-hydroxyalkanoic acids reported for this enzyme does not apply to the 5-oxo-derivatives.

Free TAA should be easily cleaved to acetoacetate and acetate by a $\beta$-diketoacid hydrolase ( $\beta$-dikelonase, EC 3.7.1.2). This enzyme occurs in various mammalian tissues and catalyzes the hydrolytic cleavage of 3,5dioxoacids such as TAA and fumaryl acetoacetate (Witter and Stotz 1948b; Meister 1949). It can also act on 2,4-dioxoacids, as reported for the pathways of gentisic and homogentisic acid degradation in liver tissue, and for the metabolism of resorcylic compounds in Pseudomonas putida (for literature, see Davey and Ribbons 1975). Nonetheless, TAA proved to be stable in the presence of $P$. acidigallici cell extracts. TAA decrease was not enhanced by removing acetoacetate from the equilibrium with 3-hydroxybutyrate dehydrogenase and NADH (Brock and Williamson 1968, 1985).

However, upon addition of catalytic amounts of acetyl-CoA, TAA was completely converted to acetyl residues, most probably catalyzed by the consecutive actions of a to date unknown acetyl-CoA:TAA CoA transferase and one or two $\beta$-ketothiolases acting on TAA-CoA and/or acetoacetyl-CoA. Lynen and Ochoa (1953) showed that acetoacetyl-CoA: acetate CoA transferase can also act on $\mathrm{C}_{5}$-homologues of 3-oxoacids; if this applies also to the 5-oxo-derivatives, acetoacetate activation with acetyl-CoA may be a side reaction of the enzyme acting on TAA (Table 2). Since succinyl-CoA could not activate TAA directly, the physiological role of the acetyl-CoA: succinate $\mathrm{COA}$ transferase activity in $P$. acidigallici-cell extracts seems to be confined to its involvement in the organism's anabolism (Brune and Schink 1990 bj, even though the specific activity is rather high.

The key enzymes of this phloroglucinol pathway were also found to be present with similar specific activities (data not shown) in P. massiliensis, which differs from $P$, acidigallici mainly with respect to its unique ability to convert hydroxyhydroquinone to phloroglucinol (Brune et al. 1991).

The aliphatic part of the phloroglucinol patbway in $P$. acidigallici (Fig. 5) differs significantly from the pathway suggested for $E$.oxidoredicens (Krumholz ct al. 1987 ), in which the reactions activating and cleaving HOHA were not completely elucidated. Contrary to $P$. acidigallici, $E$. oxidoreducens possesses high activities of 3-hydroxybutyryl-CoA dehydrogenase (NAD ${ }^{+}$). Supported by the demonstration of 3-hydroxybutyryl-CoA as the product of HOHA incubation with acetyl-CoA in the presence of cell extracts, the authors postulated a thiolytic cleavage of HOHA-CoA to 3-hydroxybutyrate and acetyl-CoA. We regard this mechanism as highly speculative because a $\beta$-hydroxyacid is rather difficult to cleave hydrolytically or thiolytically in the $\delta$-position (i.e. in $\beta$-position to a hydroxyl group). The isomeric 3-oxo-5-hydroxyhexanoyl-CoA would be a much better candidate for this reaction. For $P$. acidigallici, both isomers of HOHA are possible intermediates, since both $\beta$ - and $\delta$-oxidation of the respective isomer would yield TAA.

In contrast to $E$. oxidoreducens, $P$. acidigallici employs $\mathrm{NADP}^{+}$and not $\mathrm{NAD}^{+}$as coenzyme in $\beta$-oxidation, thus regenerating the NADPH consumed by phloroglucinol reductase. This renders $P$. acidigallic $i$ independent of external electron donors such as formate or $\mathrm{H}_{2}$, allowing the formation of 3 acetate per trihydroxybenzene and thus a higher theoretical ATP yield as compared to E. oxidoreducens, which has to release the excess electrons by butyrate formation.

The free energy change $\left(\Delta \mathrm{G}^{\circ}\right)$ of pyrogallol fermentation to 3 acctate is $158.3 \mathrm{~kJ} \mathrm{~mol}^{-1}$, as calculated for the reaction $\mathrm{C}_{6} \mathrm{H}_{6} \mathrm{O}_{3}+3 \mathrm{H}_{2} \mathrm{O} \rightarrow 3 \mathrm{C}_{2} \mathrm{H}_{3} \mathrm{O}_{2}^{-}+3 \mathrm{H}^{+}$from the $A \mathrm{G}_{\mathrm{f}} \mathrm{O}$-values published by Thauer et al. (1977) and the value for pyrogallol estimated by Kaiser and Hanselmann (1982). This free energy change allows a theoretical ATP yield of at least 2 ATP per substrate. The phloroglucinol pathway given in Fig. 5 possesses 2 substrate level phosphorylation sites per trihydroxybenzene. Yet, the molar growth yields of $P$. acidigallici with trihydroxybenzoate derivatives are in the range of $10 \mathrm{~g}$ dry cell matter per mol of substrate (Schink and Pfennig 1982), indicating that in reality the ATP yield may be smaller (Thauer et al. 1977).

Acknowledgements. This work was supported by a grant of the Deutsche Forschungsgemeinschaft, Bonn, and by a fellowship of the Deatsche Gesellschaft für Chemisches Apparatewesen. Chemische Techaik und Biotechnologie (DECHEMA), Frankfurt am Main, to A.B. We are indebted to Prof. G. Jung, Institut für Organische Chemle, and his coworkers in Tübingen, for arranging access to the H-NMR and mass spectroscopy service facilities of the Fakultät für Chemie und Pharmazie, Universität Tübingen. The assistance of Titus Kaletta is greatly appreciated. Special thanks are due to Karen $\mathrm{A}$. Brune for reading the manuseript.

\section{References}

Batclaan JG (1976) A convenient synthesis of triacetic acid methyl ester. Synthetic Commun 6:81 83

Bergmeyer HU, Gawehn K, GraBl M (1974) Acetat-Kinase. In: Bergmeyer HU (ed) Methoden der enzymatischen Analyse, 3rd edn, vol I. Verlag Chemie, Weinheim, pp 454-455

Blackwood AC, Hang YD, Robern $\mathrm{H}$, Mathur DK (1970) Reductive pathway for the degradation of phloroglucinol by a pseudomonad. Bacteriol Proc 70: 124

Bradford MM (1976) A rapid and sensitive method for the quantitation of microgram quantities of protein utilizing the principle of protein-dye binding. Anal Biochem 72: 248-254

Brock DJH, Williamson DH (1968) Purffication of a diketo acid hydrolase from rat liver and its use for the enzymic determination of 3,5-diosohexanoate (triacetate). Biochem J 110: 677-682

Brock DJH, Williamson DH (1985) Triacelate and fumarylacetoacetate. In: Bergmeyer $\mathrm{HU}$ (ed) Methods in enzymatic analysis, 3rd edn vol 8. Vezlag Chemie, Weinhcim, pp 69-73

Brune A, Schink B (1990a) Pyrogaflol-lo-phloroglucinol conversion and other hydroxyl-transfer reactions catalyzed by cell extracts of Pelobacter acidigalici. J Bacter1ol 172: 1070-1076 
Brune A, Schink B (1990b) A complete citric acid cycle in assimilatory metabolism of Pelobacter acidigallici, a strictly anaerobic, fermenting bacterium. Arch Microbiol 154:394-399

Brune A, Schnell S, Schink B (1992) Sequential transhydroxylations converting hydroxyhydroquinone to phlotoglucinol in the strictly anaerobic, fermenting bacterium, Pelobacter massiliensis. Appl Environ Microbiol (in press)

Davey JF, Ribbons DW (1975) Metabolism of resorcinylic compounds by bacteria. Purification and properties of acetylpyruvate hydrolase from Pseudontonas putida 01. I Biol Chem 250: $3826-3830$

Dimroth $P$ (1987) Sodium ion transport decarboxylases and other aspects of sadium ion cycling in bacteria. Microbiol Rev 51: $320-340$

Evans WC (1977) Biochemistry of the bacterial catabolism of aromatic compounds in anaerobic cnvironments. Nature 270: $17-22$

Evans WC, Fuchs G (1988) Anaerobic degradation of aromatic compounds. Ann Rev Microbiol 42: 289-317

Fray GI (1958) Reaction of phloroglucinol with sodium borohydride. Tetrahedron 3: 316

Haddock JD, Ferry JG (1989) Purification and properties of phloroglucinol reductase from Eubacterium oxidoreducens $\mathrm{G}-41$. J Biol Chem 264: 4423-4427

Harwood CS, Gibson J (1986) Uptake of benzoate by Rhodopseudomonas palustris grown anaerobically in light. J Bacteriol 165: 504-509

Kaiser JP, Hanselmann KW (1982) Fermentative metabolism of substituted monoaromatic compounds by a bacterial community from anaerobic sediments. Arch Microbiol 133: 185-194

Krumholz LR, Crawford RL., Hemling ME. Bryant MP (1987) Metabolism of gallate and phloroglucinol in Eubacterium oxidoreducens via 3-hydroxy-5-oxohexanoate. J Bacteriol 169: $1886-1890$

Lynen F, Ochoa S (1953) Enzymes of fatty acid metabolism. Biochim Biophys Acta 12: 299-314
Meister $\Lambda$ (1949) Metabolism of 3,5-diketohexanoic acid and its $\delta$-lactone by tissue homogenates. J Biol Chem 178: 577-589

Michal G, Bergmeyer HU (1974) Coenzym A. In: Bergmeyer HU (ed) Methoden der enzymatischen Analyse, 3rd edn, vol II. Verlag Chemie, Weinheim, pp 2020-2023

Patel TR, Jure KG, Jones GA (1981) Catabolism of phloroglucinol by the rumen anaerobe Coprococcus. Appl Environ Microbiol 42: $1010-101$ ?

Patel TR, Hameed N, Martin AM (1990) Initial steps of phloroglucinol metabolism in Penicilium simpicissimum. Arch Microbiol 153: 438-443

Platen H, Schink B (1987) Methanogenic degradation of acetone by an enrichment culture. Arch Microbiol 149: 136-141

Samain E, Albagnac G, Dubourguier HC (1986) Initial steps of catabolism of trihydroxybenzenes in Pelobacter cwidigallici. Arch Micrabiol 144: 242-244

Schink B, Pfennig N (1982) Fermentation of trihydroxybenzenes by Pelobacter acidigallici gen. nov. spec. nov., a ncw strictly anaerobic, non-sporeforming bacterium. Arch Microbiol 133: $195-201$

Schnell S, Brune A, Schink B (1991) Degradation of hydroxyhydroquinone by strictly anaerobic fermenting bacterium Pelobacter massiliensis sp. nov. Arch Microbiol 155:511-516

Snow Boles J, Crerar DA, Grissom G, Key TC (1988) Aqueous thermal degradation of gallic acid. Geochim Cosmochim Acta 52: $341-344$

Stern JR (1956) Optical properties of acetoacetyl-S-coenzyme A and its metal chelates. J Biol Chem 221: 33-44

Thauer RK, Jungermann K, Decker K (1977) Energy conservation in chemotrophic anaerobic bacteria. Bacteriol Rev 41 : $100-180$

Whittle PJ, Lunt DO, Evans WC (1976) Anaerobic photometabolism of aromatic compounds by Rhodopseudomonas sp. Biochem Soc Trans 4: $490 \quad 491$

Witter RF, Stotz E (1948a) Synthesis and properties of triacetic acid. J Biol Chem 176: 485-492

Witter RF, Stotz $\mathrm{E}$ (1948 b) The metabolism in vitro of triacetic acid and related diketoncs. J Biol Chem 176: 501-510 